\title{
Development of interprofessional collaborative practices within undergraduate programs on healthcare: case study on the Family Health Alliance in Fortaleza (Ceará, Brazil)*
}

\author{
Ivana Cristina de Holanda Cunha Barreto ${ }^{1}$ \\ Francisco Antonio Loiola ${ }^{2}$ \\ Luiz Odorico Monteiro de Andrade ${ }^{3}$ \\ Ana Ester Maria Melo Moreira ${ }^{4}$ \\ Caio Garcia Correia de Sá Cavalcanti ${ }^{5}$ \\ Carlos André Moura Arruda ${ }^{6}$ \\ André Luiz Façanha da Silva7
}

BARRETO, M.C.H.C. et al. O desenvolvimento da prática de colaboração interprofissional na graduação em saúde: estudo do caso da Liga de Saúde da Família em Fortaleza (Ceará, Brasil). Interface - Comunic., Saude, Educ., v.15, n.36, p.199-211, jan./mar. 2011.

The authors present the dynamics of mentoring work within the Family Health Alliance (FHA), an extension program that fosters interprofessional collaboration from a social learning perspective. The objective of this study was to describe and evaluate the program dynamics and their repercussions among the participants. The context, basis, objectives and organization of work situations for students from six different undergraduate programs on health sciences were analyzed by means of an exploratory development study conducted between January and December 2008. In the first phase, the participants were two teams consisting of one mentor and four students. In the second phase, there were three mentors and eight students. Thematic analysis on the students' discourse emphasized their enthusiasm about the possibility of interprofessional collaboration as an instrument for change. The professional mentors were found to have developed a better understanding of their role and greater teaching awareness.

Keywords: Interprofessional collaborative practices. Interdisciplinarity. Family health.
Os autores apresentam a dinâmica de trabalho dos mentores no interior da Liga de Saúde da Família, um programa de extensão que estimula a colaboração interprofissional, na perspectiva da aprendizagem social. O objetivo do estudo foi descrever e analisar a dinâmica do programa e suas repercussões entre os participantes. O contexto, os fundamentos, objetivos e a organização de situações de trabalho para estudantes de seis diferentes cursos de graduação em ciências da saúde são analisados por meio de uma pesquisa de desenvolvimento do objeto, exploratória, realizada de janeiro a dezembro de 2008. Na primeira fase participaram duas equipes com um mentor e quatro estudantes. Na segunda fase três mentores e oito estudantes. A análise temática do discurso dos estudantes ressaltou seu entusiasmo com as possibilidades da colaboração interprofissional como um instrumento de mudança. Dos mentores profissionais é possível apreender uma melhor compreensão do seu papel e uma maior sensibilidade pedagógica.

Palavras-chave: Práticas colaborativas interprofissionais. Interdisciplinaridade. Saúde da família.

\footnotetext{
* Unpublished article based on a study of the development of the object carried out as part of UFC extension project in partnership with the local Health Department of the City of Fortaleza and a postdoctoral internship funded by the Coordination for Improvement of Higher Education (Capes). Approved by UFC Research Ethics Committee.

${ }^{1,3}$ Federal University of Ceará Medical School on Sobral. Leonardo Mota Street, 2815, apt. 802 Fortaleza, Ce, Brasil. 60.170.041.

ivanabbarreto@ufc.br

${ }^{2}$ Faculté des Sciences de I'Éducation, Université de Montréal, Quebéc, Canada.

${ }^{4}$ Federal University of Ceará.

${ }^{5}$ Master's Degree Program in Public Health, Federal University of Ceará.

${ }^{6}$ Multiprofessional Residence in Family and Community Health of Municipal Health Secretary of Fortaleza, Ceará.

${ }^{7}$ Family Health Residence Program, School of Family Health of Sobral, Ceará.
} 


\section{Introduction}

In Brazil, recent ministerial policies for training human resources in health (Brasil, 2001) have introduced a renewed vision for training for future health professionals and recommended the adoption of new interdisciplinary teaching guidelines focused on interprofessional collaboration. Since 2006, in line with these guidelines, for the implementation of new practices, a new training space has been created at the Federal University of Ceará in partnership with the Local Health Department of the City of Fortaleza called Family Health Alliance (FHA). The FHA is a complementary training program that provides undergraduate students interdisciplinary general education and allows them to have an openminded approach to interprofessional collaboration. Described as a community service for institutional and interfaculty integration, the FHA came into being as a response to the need of promoting and strengthening interprofessional collaborative practices in primary health care.

In general, in the performance of their duties, teachers responsible for training projects with difficulty establish links among various disciplines of knowledge, learning contents, and teaching strategies to develop significant teaching-learning situations. Furthermore, they perpetuate a traditional teaching practice that they well know and relegate students to a performer role.

In the FHA, a team of teachers and professionals become mentors and work from the perspective of interprofessional collaborative practices (Soubhi, 2008; Andrade, 2004; Rege Colet, 2002). The mentoring relationship focuses on experiential learning in a context of multiple roles and functions. It is a support method that focuses on learning in context and interprofessional and interdisciplinary collaboration. But what is mentoring in the FHA? What are the mentoring characteristics applied to training for future health professionals from a perspective of interdisciplinary collaborative learning? What is the impact of the mentoring relationship on the development of interdisciplinary practices? How do students develop interdisciplinary collaboration skills within the FHA?

In line with the subject of the present issue, we present the context in which this experience has been developed and the rationale and dynamics that motivated mentoring activities within a learning context and interprofessional and interdisciplinary collaboration. A research study associated with this educational approach was started in the beginning of 2008.

\section{The research context}

In the wake of the recent reform of higher education in Brazil, several universities have been brought to develop new health programs from a professional competence perspective. This new reference, implemented by the Brazilian Ministry of Education together with institutions representing health professionals ${ }^{8}$, has made training programs aligned with a competency-based approach. The competency-based approach is an approach to education based on the adoption of problem-based learning centered on a concept of comprehensive health (Brasil, 2001).

This new view is consistent with a collective perspective set forth in the 1988 Brazilian Constitution, which has recognized the public nature of health services and established the principles of universality and equality (Brasil, 1988). It has recognized the State's obligation to provide comprehensive health care and support for training human resources required in the public health system.

\author{
${ }^{8}$ Brazilian Association of \\ Medical Education, \\ Brazilian Association of \\ Nursing, Brazilian \\ Association of Dentistry \\ Federal Council of \\ Medicine, Federal \\ Council of Nursing, \\ Federal Council of \\ Dentistry, Federal \\ Council of Pharmacy, \\ Federal Council of \\ Psychology, Federal \\ Council of \\ Physiotherapy.
}


${ }^{9}$ It is an organizational model of primary health care that was started in Brazil 15 years ago.

${ }^{10}$ Community health workers perform health education activities and promote health in their own communities.
Indeed, twenty years ago, Brazil put into practice the reform of its social security system, particularly implementing changes in the public health system. The health reform was the result of a social movement supported by health professionals, university teachers, students, union workers, and politicians. It has decentralized public health management. The National Unified Health System (SUS) has been created and is characterized by decentralization with a single administration at each level of the political system. In addition, primary care has been strengthened through the creation of the Family Health Program on $1994^{9}$.

In 2007 the Ministry of Health officially replaced the term Family Health Program for Family Health Strategy (FHS), whereas SUS is a national health system based on Primary Health Care (PHC) and the FHS was adopted as a priority in organization of PHC ( Brasil, 2007).

The FHS is a doorway for families and individuals allowing them access to the health system. FHS coordinates primary care with specially services. Its basic structure consists of an interdisciplinary family health team whose mission is to provide primary health care to eight hundred families in a given area (Andrade, Barreto, Bezerra, 2006). Each team consists of one physician, one nurse, dentists, nursing assistants and six to ten community health workers $(\mathrm{CHWs})^{10}$. Currently there are 29,900 FHS teams distributed among 5,241 Brazilian municipalities (Brasil, 2009).

FHS implementation, however, revealed that most providers in the interdisciplinary family health teams do not have a broad vision of social determinants of health and often do not see health promotion as their responsibility (Almeida, Mishima, 2001; Campos, Belisario, 2001; Ceccim 2004). Moreover, most health undergraduate programs at medical, dental and nursing schools prioritize specialized training scenarios and focus on a biomedical approach in a hospital setting.

But how to promote reflective professional training focused on the development of interprofessional collaboration competence but not limited to a biomedical approach and to the grouping of specialized tasks? What are the strategies proposed to meet the challenge of an authentic contextualized training supported by a mentor?

\section{An educational approach for learning interprofessional collaborative practices in health}

The Federal University of Ceará has encouraged the introduction of new educational initiatives in undergraduate programs. The FHA is a program of complementary training carried out in six different undergraduate programs in health (medicine, nursing, psychology, physical education, pharmacy and dental care). The main purpose of FHA is to provide students an interdisciplinary general education and allow them to have an open-minded approach to collaboration within interprofessional teams. Our first challenge is to develop a strategy that focuses on learning in context and interprofessional and interdisciplinary collaboration. For that, we have to apply a mentoring method to test a new training culture in context by the implementation of integrated training. However, the interprofessional work within the FHA groups people who work with different paradigms and thus different concepts of knowledge and training. 


\section{Mentors}

The FHA consists of a team of academic and professional mentors. The academic mentors are six teachers affiliated to the Medical School (Department of Community Health), Schools of Pharmacy, Nursing and Dentistry, and the Department of Psychology and Physical Education at the Federal University of Ceará. Mentors are responsible for planning education together with interprofessional teams and supervision of six field mentors.

Field mentors are health providers (doctors, psychologists, physical therapists, nurses, physical educators) from the city's local health department. These mentors are directly responsible for supporting interdisciplinary teams of students in activities designed to develop interprofessional collaborative health practices through professional contextualized learning experiences.

Field mentors guide students during FHA activities conducted at community health centers and in the community, i.e., in situations which are or may be part of professional activities and present a challenge to students.

The role of FHA professional mentors is not limited to the health unit; they also work in the community by facilitating the community diagnosis process and establishing links among students, organizations, and community leaders. Indeed, mentors follow a scaffolding strategy in an expanded area. They are also involved in student selection and theory discussions during meetings with students.

\section{FHA dynamics}

FHA activities are developed over a 10-month period. However, before being placed in a contextualized professional situation as a collective challenge, students are invited to attend a preparatory seminar on a common field of knowledge, that is, the study of transversal themes whose content is effectively linked to all professional fields of interest of the participating students. The themes that make up this common field of knowledge include: public health, health promotion, primary health care, family health and social determinants of health in Brazil and worldwide. This seminar is an intensive week-long session held as often as possible with the entire group, but can sometimes be attended by subgroups or teams.

After this first collaborative activity, students are asked to form interprofessional teams of five to eight members. Each team is lead by a mentor from the field of interest whose primary role is to support it. Mentors guide students in their exploration and use of various resources in their interactions, thoughts, motivations, and experiences. Each team has to select a district to be visited ${ }^{11}$. The purpose of this first visit is to establish contact with FHS teams and community representatives and then each community is visited by the team once a week for two or three months for community integration (Gois, 2008, 1993).

The purpose of this approach is to know and identify problems specific to the district involving collective challenges especially regarding public health issues. Lead by their mentor the students work in close collaboration with the local family health team. Each interprofessional team identifies problems to be ideally faced with the collaboration of the community. Each team, together with the community, selects a problem that will be investigated for further understanding it. The teams are also asked to conduct documented research studies to explore the resources available other than FHA training activities.

This activity is intended to the production of a report by each interprofessional team to be submitted to the collaborators (i.e., community representatives and

\footnotetext{
${ }^{11}$ The coordination center of the district's health units is contacted before the first visit and it is invited to participate in the FHA project.
} 
local FHA team members). This report is an instrument for addressing local living conditions and initiating a discussion on the identified needs.

Finally the next activity is a one-day symposium attended by all interprofessional teams, mentors, partners and community representatives. In the symposium each interprofessional team have to present a work plan in line with their report and developed together with the FHS team. The work plan has to include steps to thoroughly address the target issue with special emphasis given to interprofessional collaboration among team members to be implemented with community involvement.

\section{Rationale for FHA mentoring approach in contextualized professional situations}

The rationale for FHA mentoring in contextualized professional situations is based on the social perspective of learning developed by Wenger (1998). This concept of learning in terms of social participation highlights the importance of practice ("how") in the process of building an identity.

FHA training approach focusing on learning in context and interprofessional and interdisciplinary collaboration involves taking both a theoretical and practical view for socially shared learning. But what significance could be attached to different disciplinary discourses and contrasting professional cultures of health interventions? As Hasni and Lenoir (2000) noted, an interdisciplinary approach is not an easy one, and its success requires taking into account several relevant factors from an epistemological dimension and the interaction of different individuals involved in team work.

According to Andrade et al. (2004), interprofessionality requires a paradigm shift as interprofessional practices include innovative components with new values, codes of conduct and ways of working. This author claims that even today the multiprofessional health care model is what he calls a "model of parallel small houses." Figure 1 shows that health providers share the same environment and work issues, but remain isolated in their specific knowledge and methods and maintain merely formal communication.

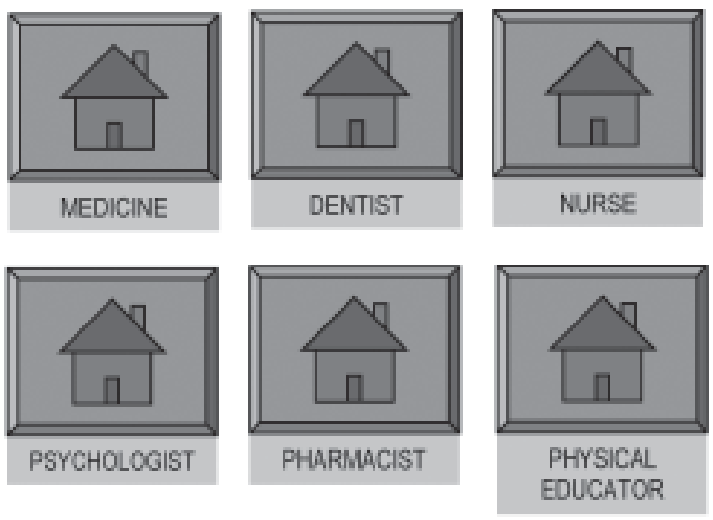

Figure 1. Model of tradicional multiprofessional work or "model of parallel small houses"

Source: Adapted from Andrade et al. (2004).

Inspired by Campos' epistemological studies (2000; 1998), Andrade et al. (2004) proposed a model of interdisciplinary work taking into account relational and collaborative dimensions from a common field of knowledge and professional practices in family health (see Figure 2).

In the FHA mentors take an approach of an interprofessional work model based on the assumption that knowledge centered on a discipline is not sufficient to find appropriate solutions to problems and 
relational and collaborative dimensions from a common field of knowledge and interprofessional practices have to be taken into account. It is through problem solving that students from several different disciplines centered on different paradigms, but referring to a common field of knowledge, come together in an interdisciplinary perspective to move from theory to action.

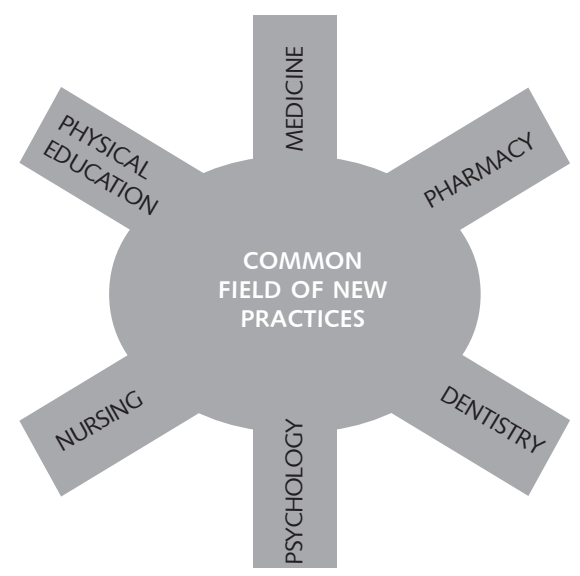

Figure 2. Model of interprofessional collaboration in the field of family health

Source: Adapted from Andrade et al. (2004).

In the FHA, as students are faced with problems, challenges, demands, tasks, or requirements, they are placed into a professional contextualized situation. As we mentioned before, professional contextualized situations are the center of FHA approach. These challenging situations require solving problems. The role of mentoring in this context becomes central for the proposed interventions are intended to help students develop strategies for collaboration in problem solving relying on both observation and guided structured application. Students are encouraged, regardless of their discipline of interest, to follow an interprofessional practice that is less fragmented and more unified (D'amour, Oandasan, 2005). By guiding learners in their exploration and exploitation of various resources in their different interactions, field mentors help students to practice in a more collaborative and integrated setting while planning and implementing joint projects. Collaboration becomes thus central to building up relationships, sharing knowledge, and holding consultations on issues and actions.

\section{Methodological considerations}

This research study is part of what Van der Maren (1996) describes as a research focused on the development of an object. As Richey, Klein and Nelson (2004, p.1099) proposed, it may take the form of a "case study involving a retrospective analysis" of the process. According to Van der Maren (1996), research can take three forms: concept development, development of an object or tool, and the development or improvement of personal skills as professional tools. Our purpose in the present study was to investigate the dynamics of educational mentoring within the FHA and the development of interprofessional collaborative practices. A qualitative study was conducted based on an interpretative paradigm to describe, analyze and understand the dimensions of collaborative sharing of professional expertise. Thus, the objective was to understand it from the perspective of people involved in the FHA rather than analyzing it for statistical or generalization considerations. 


\section{Participants}

Exploratory and descriptive study conducted in a convenience sample. The first phase involved two interprofessional teams including a mentor and four students. The second phase involved two groups including three mentors and eight students from six different undergraduate programs in health (medicine, pharmacy, dentistry, psychology, physical education and nursing). The study was approved by the Research Ethics Committee of the Federal University of Ceará and all students and mentors have signed a consent form.

\section{Data collection and analysis}

Data was collected between January and December 2008. In the first phase the researchers observed and recorded all activities carried out by two teams in health services and the community. In the second phase of the study focus group consisting of eight students and three mentors completed a self-administered questionnaire. The focus group discussed three main topics related to their experiences as students: a) the meaning of the FHA for their education; b) the importance of the FHA for strengthening actions in family health and primary health care; and c) teamwork in the FHA. The following main subjects were addressed in the self-administered questionnaire of mentors: a) their experience as a FHA mentors; b) the mentor's role in the scaffolding process; $c$ ) the impact of prior knowledge (disciplinary knowledge); d) the difficulties they encountered; e) new knowledge gained in the FHA; and f) the impact of the FHA on the development of collaborative practices within interprofessional teams.

After full transcription of data collected through questionnaires and focus group discussions, we conducted a thematic analysis (Paillé, Mucchielli, 2005) to better understand the reality as it emerges from the participants' answers and discourses. For data analysis, we first established a coding grid for the study objectives and issues described above. The coding grid was used to encode the entire text to form the basis of the categorical structure built from themes. During the codification process, we identified recurrences or clusters that helped making some new findings.

\section{Professional situations and the development of interprofessional collaborative practices}

Let us briefly describe two professional situations where students from different disciplines, but brought together by the principle of collaborative learning, are faced with needs, challenges, and mandates, which are or can be realistic replications of their workplace. It is in these contexts that collective action, created by the interdependence of activities, can lead to complementary professional practices.

\section{Professional situation 1}

Group 1 consisting of four members and led by a mentor had to accomplish community integration in the district of Pici in Fortaleza. After preparing and discussing a work plan, students were brought to work with the community to develop a strategy to identify key issues, and institutional resources available. Social vulnerability of the youth was identified as their main challenge. There were some major challenges to their work: the team should work with all community representatives and their work should involve negotiation and persuasion. For example, they should approach the community for their investigation and actually talk with young people exposed to real situations of social vulnerability. Students had to learn communication skills and devise strategies such as taking part in cultural events and meetings. The team also identified several organizations devoted to social work with adolescents in the neighborhood. As each organization worked independently, in collaboration with community representatives, students mapped out all social institutions in the district. A forum was then held with all 
these organizations and they finally reached an agreement to create an integrated network of social services targeted to adolescents.

\section{Professional situation 2}

An interprofessional group of students consisting of four members chose to undergo the process of community integration in the poor district of Pirambu in the city of Fortaleza. In collaboration with the FHS team and local leaders, students were able to identify serious health problems and the need for reliable data on families settled in an area where there was great risk of dengue fever. Under the mentor's supervision, the team developed protocols to collect information on local living conditions. With the support of CHWs, students paid home visits to 600 families who were interviewed and informed on the risk of dengue fever. There were some major challenges: to develop an appropriate protocol that was realistic to local conditions; to have good communication strategies to establish a trusting relationship with families who were under stress and feeling unsafe; to respond to medical needs; to appropriately use the information collected. The data obtained on community health provided valuable input indicating the need for quick response and action. Collaboration was urgently required between all health and educational agencies directly or indirectly involved with the families. There were held discussions with local health authorities that concluded on the need to create a center for strategic information. The student team worked in collaboration with the FHS team to establish an administrative information center that eventually supported care and prevention actions.

\section{Implementation of interprofessional collaborative practices in the Family Health Alliance in Brazil}

It should be noted that contextualized professional situations require problem solving. Students are encouraged, regardless of their discipline of interest, to follow an interprofessional practice that is less fragmented and more unified. But how to evaluate knowledge integration of two or more professional areas in a real context? Does the FHA organization encourage the integration across a work team conducive to effective sharing, experimentation and learning of a collaborative culture? In the next section, we examine the responses of our students and mentors for evidence of integrated knowledge, knowledge mobilizing in action context and innovative components with new values, conduct codes and ways of working together.

\section{Mentors' perspective: a wider learning community whose challenge is pooling learners' knowledge}

When mentors were asked about their understanding of the FHA, many of them stressed the dynamics of an interprofessional approach emerging from group work. One mentor recognized that the FHA is an innovative project with an ongoing learning process.

\footnotetext{
"The Alliance creates a wider learning community since all spaces are for building knowledge, and builds up links between education, research and community service". (mentor 1)
}

Another mentor agreed with this same idea. For him the FHA is a reflective way to learn together and strengthen cohesion among students.

\footnotetext{
"I see mentoring in the FHA project as a process to facilitate learning and move into praxis, where the mentor and students experience daily activities of health care and get familiar with community life, and reflecting about this experience based on expert concepts and personal issues". (mentor 2)
} 
Appreciation and recognition of personal skills from an interactive perspective together with a new view of performance was also highlighted.

"Mentoring in the area is a new educational activity. It is a new experience for the integration of health providers into the family health strategy. It requires a new view of performance based on the interaction with different actors from an inter-domain perspective". (mentor 3)

The interactions with interprofessional teams and the community in work contexts creates interdependence and complementarity between disciplines and providers involved.

"The FHA enables collective work with complementarity: awareness to difference, knowledge exchange, and commitment to the group. Students take a central role. It is the study of other fields of knowledge besides health, and the process of community involvement makes it possible to gain popular knowledge". (mentor 2)

Field mentoring is an activity where practices and knowledge are under construction. Some mentors had to break with certain rigid academic standards with differentiation of professional action areas.

"First, as a mentor, I came across a big challenge because my general education has been focused on clinical practice in hospital and outpatient care settings. But later the challenge became a positive experience". (mentor 2)

The challenging and innovative nature of mentoring engendered uncertainty, but also aroused feelings of satisfaction when advances in projects were achieved by interprofessional teams.

"The beginning of the project was highly experimental, built from field expertise. Over time we developed reflection paths based on concepts of education, didactics and teaching methods". (mentor 1)

Mentors highlighted the application of general knowledge acquired during their academic training on the FHA:

"The contribution of each team member was not necessarily in their specific professional field, because sometimes individual life experience contributed greatly to the team". (mentor 3)

\section{Students' perspective}

In focus groups, we recorded the students' perceptions about their experience in the FHA. Some recalled that in the beginning they were all interested but concerned.

"[...] It is important to note that the first few weeks of work were marked by curiosity and anxiety in the group. We discovered a different reality from what we are used to as university students. Our university experience has been more theoretical, rational and less complex". (student 2)

The exchange of ideas between mentors and their students helped reassure them about their skills and make adjustments as needed. One student said the mentor helped them better understand the importance of collaborative work: 
"With the exchange of ideas with our mentor, we could understand the process of integration as a collective effort involving both our team and the community itself". (student 4)

Students recalled their progress regarding teamwork. They stressed the experiment was a professional trial that made them develop tolerance and the ability to listen to their colleagues.

"In the FHA, at first I felt I belonged to one professional area, which was not bad. However, we realize that this apparently safe territory has its limitations as we share our commitment with students from other areas. It is a vocational trial. In this context we all make mistakes but the involvement with other people assures you much more". (student 1)

"We often want to say what we think, we believe we are right, we want to impose ourselves... In the group, while working in team, we learn a lot and each one gives his/her own opinion, and we try to reach an agreement [...] we try to reach a real consensus. It happens often". (student 2)

The fact that each student in the FHA was from a different discipline certainly enriched interprofessional work. This pooling of knowledge helped achieving complementarity between students. Each student, influenced by the models and lingo of their field of knowledge, had the opportunity to talk about their career perspective. This student also said she felt appreciated when participating in interdisciplinary work:

"[...] the most valuable aspect of this project, I believe, was the interdisciplinary one... I have already participated in other projects that were also rich in terms of theory and motivation, but there was no interdisciplinary approach. Therefore, I believe the FHA is different. Here we often talk to other students who have different views, right? We may have different ideas but we try to reach a consensus. It is often difficult but rewarding". (student 3)

The perceived importance of experience in the FHA is also a potential source of appreciation. As this student stated, the experimental program goes beyond the formal curriculum offered in traditional programs at the university.

"I think this project is very important because it provides a training program that departs from the official curriculum; it avoids the one-way exchange of ideas between the teacher and their students. Here I can see and live my vision, my analysis, the contribution of my profession in the field, to the community, to the family health program". (student 5)

"I think students who participated in this project, or, who will participate, will have an enriched and differentiated learning. When we talk with other colleagues, we can see differences in training". (student 5) 


\section{Conclusions}

The development of professional situations conducive to interprofessional collaboration is a complex challenge. The purpose of the present study was to further understand the impact of mentoring on the development of interdisciplinary practices in an authentic professional context.

Traditionally, mentoring models in health in Brazil are more frequently applied in hospital settings or postgraduate programs. Mentoring by health providers carried out in the family health program in Brazilian urban areas is a recently developed activity. Another aspect to take into account in field mentoring in the FHA is the dynamic application of theory and practical knowledge of public health and primary health care for the development of basic skills in each profession.

Although this exploratory study does not allow generalizations, it shows, however, the importance of considering several new thinking ways. Perceptions and feedbacks from students and mentors contributed to this exploratory research by providing input on the potential of the FHA as well as the role of mentoring in the development of collaborative practices in professional contexts.

The thematic reading of students' discourses highlighted their enthusiasm with the possibilities that collaboration can bring as an instrument of change in health. Field mentors' discourses provided a better understanding of their role and showed better educational sensitivity regarding teaching approaches of projects and problem solving. The study also revealed that the very interaction between mentors and students, and between students and the community, is a triggering and promising component that necessarily relies on co-construction of knowledge by mentors and their students.

Based on the theoretical framework of communities of practice, we can consider that this reflective process of the Family Health Alliance helped the development of a common identity, alignment and migration of students and mentors to the heart of the community of practice in family health (Wenger, 1998). Democratic internal relations and encouragement of theoretical and practice actions by students allowed them to develop their imagination and sense of belonging, two characteristics of a community of practice (Wenger, 1998).

Exploring the representation students have of their own disciplinary fields is important as it affects the beliefs, intentions and practices of professional practitioners. It appears, however, that there are numerous concepts and that the representations of their integration into professional and learning activities are not consistent. Still, it is a positive aspect as this diversity of views and approaches can be used to free students and mentors from their disciplinary boundaries and foster interprofessional collaboration.

\section{Collaborators}

Ivana Cristina de Holanda Cunha Barreto and Francisco Antonio Loiola were responsible for all stages of the production of this manuscript. Luiz Odorico Monteiro de Andrade was responsible for data analysis and text review. Ana Ester Maria Melo Moreira, Caio Garcia Correia de Sá Cavalcanti and André Luiz Façanha da Silva were responsible for the development of the research project, organization of the focus group, and text review. Carlos André Moura Arrudawas responsible for drafting the questions and coordinated the focus group with students. 


\section{References}

ALMEIDA, M.C.P.; MISHIMA, S.M. O desafio do trabalho em equipe na atenção à Saúde da Família: construindo "novas autonomias" no trabalho. Interface - Comunic., Saude, Educ., v.5, n.9, p.150-3, 2001.

ANDRADE, L.O.M.; BARRETO, I.C.H.C.; BEZERRA, R.C. Atenção primária à saúde e estratégia saúde da família. In: CAMPOS, G.W.S.; MINAYO, M.C.S.; AKERMAN, M. (Orgs.). Tratado de saúde coletiva. São Paulo: Hucitec, 2006. p.783-836.

ANDRADE, L.O.M. et al. Escola de formação em saúde da família Visconde de Sabóia, Sobral, CE: uma resposta municipal para educação permanente no SUS. Divulg. Saude Debate, n.30, p.15-25, 2004.

BRASIL. Constituição da República Federativa do Brasil. Promulgada em 5 de outubro de 1988. Disponível em: <http://www.planalto.gov.br>. Acesso em: 15 ago. 2009.

Conselho Nacional de Educação. Câmara de Educação Superior. Diretrizes Curriculares Nacionais do curso de graduação em Medicina: resolução CNE/CES n 4 , de 7 de novembro de 2001. Brasília: Ministério da Educação, 2001. p.1-6.

Ministério da Saúde. Política Nacional de Atenção Básica. Brasília, 2007.

- Ministério da Saúde. Situação de implantação de equipes de saúde da família, saúde bucal e agentes comunitários de saúde. Brasília: Ministério da Saúde, 2009. Disponível em: <http://dtr2004.saude.gov.br/dab/abnumeros.php\#historico>. Acesso em: 10 set. 2009.

CAMPOS, F.E.; BELISÁRIO, S.A. O Programa de Saúde da Família e os desafios para a formação profissional e a educação continuada. Interface - Comunic., Saude, Educ., v.5, n.9, p.133-42, 2001.

CAMPOS, G.W.S. Saúde pública e saúde coletiva: campo e núcleo de saberes e práticas. Cienc. Saude Colet., v.5, n.2, p.219-30, 2000.

An anti-Taylorist approach for establishing a co-governance model for health care institutions in order to produce freedom and commitment. Cad. Saude Publica, v.14, n.4, p.863-70, 1998.

CECCIM, R.B.; FEUERWERKER, L.C.M. Mudança na graduação das profissões de saúde sob o eixo da integralidade. Cad. Saude Publica, v.20, n.5, p.1400-10, 2004.

D'AMOUR, D.; OANDASAN, I. Interprofessionality as the field of interprofessional practice and interprofessional education: an emerging concept. J. Interprofessional Care, v.19, supl.1, p.8.20, 2005.

GÓIS, C.W.L. Saúde comunitária: pensar e fazer. São Paulo: Hucitec, 2008.

Noções de psicologia comunitária. Fortaleza: Edições UFC, 1993.

HASNI, A.; LENOIR, Y. La place de la dimension organisationnelle dans I'interdisciplinarité: les facteurs influençant les pratiques de recherche et d'enseignement. In: LENOIR, Y.; REY, B.; FAZENDA, I. (Orgs.). Les fondements de I'interdisciplinarité dans la formation à l'enseignement. Sherbrooke: Éditions du CRP, 2000. p.191-218.

PAILLE, P.; MUCCHIELLI, A. L'analyse qualitative en sciences humaines et sociales. Paris: Armand Colin, 2005.

REGE COLET, N. Enseignement universitaire et interdisciplinarité: un cadre pour analyser, agir et évaluer. Bruxelles: De Boeck \& Larcier, 2002.

RICHEY, R.C.; KLEIN, J.D.; NELSON, W.A. Developmental research: studies of instructional design and development. In: DANS, D.H.; JONASSEN, D.H. (Orgs.). Handbook of research for educational communications and technology. 2.ed. San Francisco: Mahwah, 2004. p.1099-130. 
SOUBHI, $\mathrm{H}$. et al. Interprofessional learning in the trenches: fostering collective capability. J. Interprof. Care, v.23, n.1, p.52-7, 2009. Disponível em: $<$ http://www.ncbi.nlm.nih.gov/entrez/query.fcgi?cmd=Retrieve \&db= PubMed\&dopt $=$ Citation\&list_uids=19142783>. Acesso em: $10 \mathrm{dez} .2009$.

Vers la création de milieux exemplaires d'apprentissage et de développement des pratiques de collaboration interprofessionnelle centrée sur les patients atteints de maladies chroniques par la mise en place de communautés de pratique. Rapport Final soumie à Santé Canada: phase I Du projet ECIP. Montreal: Santé Canada, 2008.

VAN DER MAREN, J. Les démarches de la recherche apliquée. In: CHENÉ, A. Méthodes de recherche pour l'éducation. Montréal: Les Presses de L'Université de Montréal, 1996. p.158-84.

WENGER, E. Communities of practice: learning, meaning, and identity. New York: Cambrige University Press, 1998.

BARRETO, M.C.H.C. et al. El desarrollo de la práctica de la colaboración interprofesional en la graduación en salud: estudio del caso de la Liga de Salud de la Familia en Fortaleza (Ceará, Brasil). Interface - Comunic., Saude, Educ., v.15, n.36, p.199-211, jan./mar. 2011.

Los autores presentan la dinámica de trabajo de los mentores en el interior de la Liga de Salud de la Familia, un programa de extensión que estimula la colaboración inter-profesional en la perspectiva de aprendizaje social. El estudio describe y analiza la dinámica del programa y sus repercusiones entre los participantes. Contexto, fundamentos, objetivos y la organización de situaciones de trabajo para estudiantes de seis diferentes cursos de graduación en ciencias de salud se analizan por medio de una investigación de desarrollo del objeto realizada de enero a diciembre de 2008 . El análisis temático del discurso de los estudiantes resalta su entusiasmo con las posibilidades de colaboración inter-profesional como un instrumento de cambio.

Palabras clave: Prácticas de colaboración de colaboración inter-profesional. Inter-disciplinaridad. Salud de la família. 